\title{
Whistleblowers and Corruption in India: A Critical Analysis
}

\author{
Dr. Meenu* \\ *Corresponding Author \\ Dr. Meenu

\section{Article History} \\ Received: 08.06.2020 \\ Accepted: 05.07.2020 \\ Published: 12.07.2020
}

Associate Professor, Department of Public Administration, Royal Global University, Guwahati, Assam, India

\begin{abstract}
A whistleblower is a person who exposes any kind of illegal activity in our society and plays a crucial role in providing information about corrupt practices in any organization. Whistleblowers in our society are also exposed too much harassment in public life although protection is provided to them by law. United States civic activist Ralph Nader is said to have coined the phrase, but he, in fact, put a positive spin on the term. The whistleblower's protection Act, 2014 provides a mechanism for receiving and inquiring into public interest disclosures against the act of corruption, willful misuse of a power of discretion or criminal offense by public servants. The whistleblowers' protection (amendment) bill,2015, prohibits the reporting of a corruption-related disclosure if it falls under any ten categories of informationeconomic, scientific interest, the security of the nation, cabinet proceeding, intellectual property and that received in a fiduciary capacity. It is felt that these restrictions on whistleblowers make the exposure of scams in Indian administration impossible.
\end{abstract}

Keywords: Whistleblowers, Corruption, The official secret Act 1923, Anonymity, Transparency.

\section{INTRODUCTION}

An Australian non-government organization Blueprint for Free Speech, Transparency International Australia, Griffith University and Melbourne University rates India as one of the countries that do the least to ensure that whistleblowers can speak out without fear of retribution.

The whistleblower protection program in the United States of America, which is rated highly in the report, also has certain restrictions on information that can be disclosed, but the list of restricted information is much smaller. In the US, information on defense and foreign affairs is exempted only if there is a special executive order to keep the information classified. The law in the US also doesn't cover information the revealing of which is disallowed by any other law.

Over the past five years, some 150 whistleblowers have allegedly been harassed or jailed for exposing corruption; while as many as 20 have been killed in India.

\section{The official secret Act 1923}

The official secret Act 1923 implemented by the British government in India was regarding the disallowing of any information schemes, programs, actions of the government outside the office. Such disclosure of official information can endanger the security of the state and country. Under this Act, punishment provisions are from three to fourteen years of imprisonment. But this Act is contradictory to the right to information, transparency in administration.

In 2003, The Law Commission of India in 2003considered the adoption of the Public Interest Disclosure (Protection of Informers) Act, 2002. The public interest disclosure and protection of person making disclosure bill, 2010 was introduced in August 2010, in the Loksabha. It was decided to rename these bills as whistleblowers protection bill, 2011. The president of India signed the bill on May 9, 2014 and it became the whistleblowers' protection Act, 2011.

Copyright @ 2020: This is an open-access article distributed under the terms of the Creative Commons Attribution license which permits unrestricted use, distribution, and reproduction in any medium for non commercial use (NonCommercial, or CC-BY-NC) provided the original author and source are credited. 


\section{The Whistleblower Protection Act, 2011}

Three categories of the disclosure are protected:

- First, offenses or attempts under the Prevention of Corruption Act, 1988, which include inter alia acceptance by a public servant of a bribe or having assets disproportionate to legitimate sources of income;

- Second, willful misuse of power or discretion resulting in loss to the government or wrongful gain to another;

- Third, attempt or commission of a criminal offense by a public servant.

The Act protects a complainant against being "victimized". Protection, however, is not sua sponte or automatic - in order to obtain redress the person being victimized must file an application with the relevant competent authority. The burden then shifts to the public authority (typically the employer) to prove that the person is not being victimized. Although victimizing the complainant is prohibited, it is not in and of itself an express offense under the Act.

\section{Anonymity of Whistleblowers}

Under the Whistleblower Act, a complaint cannot be filed anonymously.

1. The Act expressly states that no action will be taken if disclosure does not indicate the identity of the complainant. This is a serious shortcoming in the Act. While the whistleblower cannot remain anonymous, the receiving competent authority is required to conceal the identity of the complainant. Certain exceptions may apply.

2. Thus, the complainant must rely entirely on the competent authority as regards to protecting his or her identity.

3. By contrast, under US laws that provide for monetary rewards, the complainant can remain anonymous even while seeking a reward, so long as the complainant acts through legal counsel.

4. The first aim of any whistleblower law is to prevent the person from making the disclosure from being victimized, dismissed or treated unfairly in any other way for having revealed the information. The most effective way of protecting whistleblowers is to maintain uncompromising confidentiality regarding their identity and the content of their disclosures.

5. People are often aware of misconduct but are frightened to report it. They will only come forward if they are assured the strictest protection against retaliation, and not revealing their identity is a critical safeguard to them.

\section{Whistleblower law}

In addition to "external" whistleblower laws, companies in India are required to have similar internal reporting mechanisms. The Companies Act, 2013 which came into effect in 2014 requires companies to establish a "vigilance mechanism" to report genuine concerns and provide for "adequate safeguards against victimization" of people who report misconduct. Certain exceptions may apply.

Under the Whistleblower Act, the "competent authority" is charged with accepting and acting on complaints and safeguarding the complainant against retaliation.

No specific entity is the competent authority; rather various entities (including the Prime Minister, Central or State Vigilance Commission and the jurisdictional High Court) are the competent authority depending on the status of the person against whose misconduct the complaint is made. Accordingly, the competent authority is an amorphous category of a wide range of governmental authorities.

The Whistleblower Act provides only for a single level of competent authority to which complaints can be made, with no mechanism to escalate to a second higher level if the complainant wants to. The global consensus is that whistleblower law should provide for at least two levels of institutions. The first level should be comprised of entities such as an independent ombudsman within the organization for which the whistleblower works, or if the whistleblower is a public servant, he or she should be enabled to report to an anti-corruption agency or an auditor general. In addition, whistleblowers should be allowed to turn to the second level of authority if needed, such as designated members of the legislature, the government or the media.

\section{Official amendment-August 2013}

The information cannot be disclosed if it is related to sovereignty and integrity of India, the security, strategic, scientific or economic interest of the state, relations with foreign states, proceedings of cabinet records of deliberations of the council of ministers, secretaries and other officers except as provided under the RTI Act, 2005.

Section 8 of the Act provides that no person is required to answer any question, produce any document or render any assistance to any inquiry under the Act under certain circumstances related to scientific or economic interests. There is a need for a certificate by an authority of the state or central government with regard to the information.

The bill clarifies that if the offense has been committed with the consent of, or is attributable to, any neglect on the part of any officer, other than the need of the Department and then such officer shall also be considered to be guilty of that offense. 


\section{Whistleblowers Protection Act, 2014}

1. Any person can make a public interest disclosure before the authority.

2. Section 8 of the Act provides that no person is required to answer any question, produce any document or render any assistance in any inquiry under the Act, under the certain circumstances that relate to the sovereignty, security and integrity of India, friendly relations with foreign country, in relation to contempt of court, public order, decency or morality, defamation or incitement to an offence. It includes information like the disclosure of cabinet proceedings of the center or states.

3. Section 18(2) of the Act states that if an offense has been committed with the consent of or is attributable; such officer shall also be considered to be guilty of that offense.

\section{Whistleblowers protection (amendment) bill 2015}

1. The information related to safety, sovereignty, integrity, security, affecting national interest relating to economy and nation, proceedings related to cabinet meetings cannot be disclosed.

2. The information cannot be disclosed if the information has been expressly forbidden to be published by any court or tribunal or if the disclosure of information may result in contempt of court.

3. The information cannot be disclosed if the information can cause a breach of privilege of parliament or state legislature.

4. There is a restriction imposed on the information related to commercial confidence, trade secrets, intellectual property except information obtained in the RTI Act, 2005

5. The information can be disclosed if it can be obtained under the RTI Act, 2005 by a person in his fiduciary capacity.

6. 6.The information received in confidence from a distant government, the knowledge will the life or physical safety of a someone or the establish the supply of knowledge given in confidence for law enforcement or security purpose, the information impedes the process of investigation, prosecution of offenders, information causes unwarranted invasion of privacy, are all a restricted by the Act.

\section{Amendment to whistleblowers protection act}

1. The proposed amendment gives an absolute right to whistleblowers to make a complaint and recommends restrictions like exemptions from disclosure under the RTI Act.

2. It allows disclosure of offences of corruption recognized under the prevention of corruption Act, 1989 or attempts to commit such offences, willful misuse of power or discretion to cause demonstrable loss to the government or demonstrable wrongful gain to the public servant or a third party and commission or attempt to commit any offense recognized under any law for the time being in force.

3. It restricts the disclosure of information that would prejudicially affect the sovereignty, integrity, defense, and security, strategic, economic and scientific interest of the country besides its foreign relation.

4. The information related to commercial confidence, trade secrets, intellectual property right, related to the privacy of an individual should be obtained under the RTI Act 2005.

\section{Amendment to protection to whistleblowers Act is a positive step}

1. Today many people create rumors of false information to distract the attention of higher officers from urgent, vigilant and confidential assignments. So, to get rid of false rumors and to pay attention to work, this amendment is very fruitful.

2. Information obtained under the RTI Act 2005, paves the way for serious, speedy inquiry and investigation and save the time of investigating agencies.

\section{Criticism of the amendment to protection to whistleblowers Act}

1. The restrictions imposed on the whistleblowers are absurd. The amendments make the scams impossible to be exposed.

2. The whistleblowers will not be able to complain against defense procurements or wrongdoing in the stock exchange or failure of intelligence agencies or military strategies.

3. The whistleblowers will not be able to complain about environmental pollution or degradation of the ecology caused.

4. The whistleblowers will not be able to blow the whistle against the bribery unless he or she obtains information under the RTI Act.

5. There is an extension in the circumstances in which information cannot be disclosed, it is felt that the amendment is taking away from the effectiveness of the original Act.

6. In some cases after obtaining information under RTI Act, 2005 and showing the information with a wrong decision which is taken by the higher authorities, the attitude of the higher authorities concerned, is not positive and they want to adhere to their previous decisions only. The whistleblowers or affected person is not able to face the group of higher official performing the wrong work or taking the wrong decision. 


\section{Active Enforcement is Essential}

The main purpose of whistleblower laws is to provide protection for insiders who report cases of malfeasance, corruption or other abuse of authority. Potential whistleblowers will be affected not by the mere existence of a law, but by a plausible assurance that they will actually be protected from consequences that may range from minor harassment to murder.

The amendment bill adds other grounds on which information is exempt from disclosure, such as:

- For the informant Act to be effective, it's so essential that or not it's actively implemented and administered which this can be without delay apparent.

- Information with reference to business confidence, trade secrets or belongings, the revealing of which might hurt the competitive position of a 3rd party, unless such info has been disclosed to the litigant underneath the provisions of the correct to info Act, 2005;

- The information which is available to a person in his fiduciary capacity or relationship, unless such information has been disclosed to the complainant under the provisions of the Right to Information Act, 2005;

- Information, the speech act of which might endanger the life or physical safety of someone or determine the supply of data or help given in confidence for enforcement or security purposes;

- Information, which would impede the process of investigation or apprehension or prosecution of offenders?

- Personal info, the revealing of that has no relationship to any public activity or interest, or which might cause unwarranted invasion of the privacy of the individual, unless such info has been disclosed to the complainant under the provisions of the Right to Information Act, 2005.

Because of the extension to the circumstances in which information does not have to be disclosed, it is felt that the Amendment is taking away from the effectiveness of the original Act

- The Act seeks to protect whistleblowers, i.e. persons creating a public interest revealing associated with associate act of corruption, misuse of power, or criminal offense by an employee.

- Any public servant or any other person including a non-governmental organization may make such a disclosure to the Central or State Vigilance Commission.

- Every complaint has to include the identity of the complainant.

- The Vigilance Commission shall not disclose the identity of the complainant except to the head of the department if he deems it necessary. The Act penalizes any person who has disclosed the identity of the complainant.

\section{The Act prescribes penalties for knowingly making false complaints}

(1) Under the original Act, a whistleblower was immunized from prosecution under the Official Secrets Act, 1923 for blowing the whistle on wrongdoing in government. The Amendment Bill seeks to take away this immunity- so in theory, no officer or RTI user may come forward to blow the whistle for fear of prosecution under the Official Secrets Act, 1923. This amendment trashes the principle of 'safe alternative to silence' which should underpin all whistleblower protection laws.

In other words, unless the whistleblower is able to prove that he/she obtained his evidence of wrongdoing under the RTI Act, he/she can be punished for attaching such records to his whistleblower complaint (a mandatory requirement for the competent authority to take a whistleblower complaint seriously)- so no officer or RTI user will come forward to blow the whistle on wrongdoing unless he obtains the information after the concerned Information Commission orders its disclosure in public interest under Section 8(2) of the RTI Act.

(2) In the matter of the Indirect Tax Practitioners Association vs. R K Jain [(2010) 8SCC 281], the Supreme Court of India recognized whistleblowing to the media as a legitimate exercise if all other available options proved to be useless or uninterested. The proposed amendments do not legitimize whistle blowing to the media. In fact, journalists will continue to be prosecuted under the Official Secrets Act, 1923 for blowing the whistle on wrongdoing with no protection under the Whistleblowers' Protection Act.

\section{REFERENCES}

1. Dhawan, H. (2015). Centre Tries to Dilute Bill on Whistleblowers, The Times of India, August 5.

2. The Whistle Blowers Protection (Amendment) Bill. (2015). Pre Legislative Research, Delhi.

3. Hesch, J. (2009). Whistle blowing, A Guide to Government Reward Program, Goshan Press,

4. Hunt, G. (2000). Whistle blowing, Accountabilities and Ethical Accounting, Clinical Risk, India

5. The Whistle Blowers Protection (Amendment) Bill. (2005). Solomon and Company. 